\section{Yongsik Kim \\ Tae-Ju Oh \\ Carl E. Misch \\ Hom-Lay Wang}

\title{
Occlusal considerations in implant therapy: clinical guidelines with biomechanical rationale
}

Key words: dental implant, implant longevity, implant occlusion, overloading

\author{
Authors' affiliations: \\ Yongsik Kim, Tae-Ju Oh, Carl E. Misch, Hom-Lay \\ Wang, Department of Periodontics/Prevention/ \\ Geriatrics, University of Michigan School of \\ Dentistry, Ann Arbor, MI, USA

\section{Correspondence to:} \\ Prof. Hom-Lay Wang \\ Department of Periodontics/Prevention/Geriatrics \\ University of Michigan School of Dentistry \\ Io I I North University Avenue \\ Ann Arbor, MI 48 I09-I078 \\ USA \\ Tel.: + I-734-763-3383 \\ Fax: + I-734-936-0374 \\ e-mail: homlay@umich.edu
}

Date:

Accepted 5 January 2004

To cite this article:

Kim Y, Oh T-J, Misch CE, Wang H-L. Occlusal considerations in implant therapy: clinical guidelines with biomechanical rationale.

Clin. Oral Impl. Res. I6, 2005; 26-35

doi: IO. I I I I/j. I600-050I.2004.01067.x

\begin{abstract}
Due to lack of the periodontal ligament, osseointegrated implants, unlike natural teeth, react biomechanically in a different fashion to occlusal force. It is therefore believed that dental implants may be more prone to occlusal overloading, which is often regarded as one of the potential causes for peri-implant bone loss and failure of the implant/implant prosthesis. Overloading factors that may negatively influence on implant longevity include large cantilevers, parafunctions, improper occlusal designs, and premature contacts. Hence, it is important to control implant occlusion within physiologic limit and thus provide optimal implant load to ensure a long-term implant success. The purposes of this paper are to discuss the importance of implant occlusion for implant longevity and to provide clinical guidelines of optimal implant occlusion and possible solutions managing complications related to implant occlusion. It must be emphasized that currently there is no evidencebased, implant-specific concept of occlusion. Future studies in this area are needed to clarify the relationship between occlusion and implant success.
\end{abstract}

Occlusal overload is often regarded as one of the main causes for peri-implant bone loss and implant/implant prosthesis failure. Studies have suggested that occlusal overload may contribute to implant bone loss and/or loss of osseointegration of successfully integrated implants (Adell et al. I98I; Rosenberg et al. I99I; Quirynen et al. I992; Rangert et al. I995; Isidor I996, I997; Miyata et al. 2000). In contrast, others believed that peri-implant bone loss and/or deosseointegration are primarily associated with biological complications such as peri-implant infection (Tonetti \& Schmid I994; Lang et al. 2000). They questioned the causality of occlusal overloading for peri-implant tissue loss due to insufficient scientific evidences. However, it needs to be stressed that occlusal overload can cause mechanical complications on dental implants and implant prostheses such as screw loosening and/or fracture, prosthesis fracture, and implant fracture, eventually leading to compromised implant longevity (Schwarz 2000).

Unlike natural teeth, osseointegrated implants are ankylosed to surrounding bone without the periodontal ligament (PDL), which provides mechanoreceptors as well as shock-absorbing function (Schulte I995). Moreover, the crestal bone around dental implants may act as a fulcrum point for lever action when a force (bending moment) is applied, indicating that peri-implant tissues could be more susceptible to crestal bone loss by applying force. Literature has reported that the clinical success and longevity of dental implants can be achieved by biomechanically controlled occlusion (Rangert et al. I989, I997; Adell et al. I990; Misch 
I993). Hence, it is essential for clinicians to understand inherent differences between teeth and implants and how force, either normal or excessive force, may influence on implants under occlusal loading.

Currently, scientific evidence with regard to implant occlusion is insufficient, limited to mainly in vitro, animal, and retrospective studies (Taylor et al. 2000). Therefore, the purposes of this paper are to discuss the importance of implant occlusion for implant longevity and to provide clinical guidelines of optimal implant occlusion based on the currently available literature. In addition, possible solutions managing complications related to implant occlusion are proposed.

\section{Implant occlusion}

\section{Differences between teeth and implants}

The biophysiologic differences between a natural tooth and endosseous dental implant are well known, but potential biomechanical characteristics derived from the differences remain controversial (Rangert et al. I99I; Cho \& Chee I992; Lundgren \& Laurell I994; Schulte I995; Glantz \& Nilner I998). Differences between teeth and dental implants are summarized in Table I.

The fundamental, inherent difference between the tooth and implant is that an endosseous implant is in direct contact with the bone while a natural tooth is suspended by PDL. The mean values of axial displacement of teeth in the socket are $25-100 \mu \mathrm{m}$, whereas the range of motion of osseointegrated dental implants has been reported approximately $3-5 \mu \mathrm{m}$ (Sekine et al. I986; Schulte I995). PDL is functionally oriented toward an axial load, which leads to the physiological-functional adjustment of occlusal stress along the axis of the tooth and periodontal-functional adaptability to changing stress conditions (Lindhe \& Karring I998). Furthermore, the tooth mobility from PDL can provide adaptability to jaw skeletal deformation or torsion in natural teeth (Schulte I995). However, dental implants do not possess those advantages due to the lack of PDL.

Upon load, the movement of a natural tooth begins with the initial phase of periodontal compliance that is primarily nonlinear and complex, followed by the secondary movement phase occurring with the engagement of the alveolar bone (Sekine et al. I986). In contrast, a loaded implant initially deflects in a linear and elastic pattern, and the movement of the implant under load is dependent on elastic deformation of the bone. Under load, the compressibility and deformability of PDL in natural teeth can make differences in force adaptation compared with osseointegrated implants. To accommodate the disadvantageous kinetics associated with dental implants, gradient loading was suggested (Misch I993; Schulte r995). A natural tooth moves rapidly 56-108 $\mu \mathrm{m}$ and rotates at the apical third of the root upon a lateral load (Parfitt I960), and the lateral force on the tooth is diminished immediately from the crest of bone along the root (Hillam I973). On the other hand, the movement of an implant occurs gradually, reaching up to about IO-50 $\mu \mathrm{m}$ under a similar lateral load. In addition, there is concentration of greater forces at the crest of surrounding bone of dental implants without any rotation of implants (Sekine et al. I986). Richter (I998) also reported that a transverse load and clenching at centric contacts resulted in the highest stress in the crestal bone. The studies suggested that the implant sustains a higher proportion of loads concentrated on the crest of surrounding bone.

In natural teeth, PDL has neurophysiological receptor functions, which transmit information of nerve ends with corresponding reflex control to the central nervous system. The presence or absence of the PDL functions makes a remarkable difference in detecting early phase of occlusal force between teeth and implants (Schulte I995). Jacobs \& van Steenberghe (I993) evaluated occlusal awareness by use of the perception of an occlusal interference. They found that interference perceptions of natural teeth and implants with opposing teeth were approximately 20 and $48 \mu \mathrm{m}$, respectively. In another study (MericskeStern et al. I995), oral tactile sensibility was measured by testing steel foils. The detection threshold of minimal pressure was significantly higher on implants than on natural teeth (3.2 vs. 2.6 foils). Similar findings were also reported by Hämmerle

Table 1. Comparison between tooth and implant

\begin{tabular}{|c|c|c|}
\hline & Tooth & Implant \\
\hline $\begin{array}{l}\text { Tactile sensitivity } \\
\text { (Mericske-Stern et al. 1995) }\end{array}$ & High & Low \\
\hline $\begin{array}{l}\text { Axial mobility } \\
\quad \text { (Sekine et al. 1986; Schulte 1995) }\end{array}$ & $25-100 \mu \mathrm{m}$ & $3-5 \mu \mathrm{m}$ \\
\hline $\begin{array}{l}\text { Movement patterns } \\
\text { (Schulte 1995) }\end{array}$ & $\begin{array}{l}\text { Primary: immediate movement } \\
\text { Secondary: gradual movement }\end{array}$ & Gradual movement \\
\hline Fulcrum to lateral force & Apical third of root (Parfitt 1960) & Crestal bone (Sekine et al. 1986) \\
\hline
\end{tabular}


et al. (1995) in which the mean threshold value of tactile perception for implants (I00.6 g) was 8.75 times higher than that of natural teeth (I I. $5 \mathrm{~g}$ ). From the results of the above studies, it can be speculated that osseointegrated implants without periodontal receptors would be more susceptible to occlusal overloading because the loadsharing ability, adaptation to occlusal force, and mechanoperception are significantly reduced in dental implants.

\section{Overloading factors of implant occlusion}

A large cantilever of an implant prosthesis can generate overloading, possibly resulting in peri-implant bone loss and prosthetic failures (Lindquist et al. 1988; Quirynen et al. I992; Shackleton et al. 1994). Duyck et al. (2000) reported that the loading position on fixed full-arch implant-supported prostheses could affect the resulting force on each of supporting implants. When a biting force was applied to the distal cantilever, the highest axial forces and bending moments were recorded on the distal implants, which were more pronounced in the prostheses supported by only three implants as compared with prostheses with five or six implants. In a series of studies, it was found that closing and chewing forces increased distally along the cantilever beams when occluding with complete denture and decreased distally when occluding with fixed partial dentures (Falk et al. I989, I990; Lundgren et al. I989). The displacement of complete denture during function might create heavy occlusal contacts on the posterior cantilever segment. This finding suggested that simultaneous occlusal contacts along the prosthesis were significant, and the number and distribution of occlusal contacts on cantilever segments should be controlled carefully with the opposing complete denture. Interestingly, Lindquist et al. (I988) noted more peri-implant bone loss at the anterior implants in patients treated with mandibular fixed implant-supported prostheses with distal cantilevers. Later, the same group reported that peri-implant bone loss was mainly correlated with poor oral hygiene and smoking, not with occlusal overload (Lindquist et al. 1996, 1997). Currently, the correlation between implant bone loss and overloading induced by cantilevers remains unanswered. However, it cannot be disregarded that a cantilever, especially a long cantilever, may introduce a larger force on the implant prosthesis, depending on the position and direction of force, which may result in overloading on supporting implants. Regarding a cantilever length, a clinical study demonstrated that long cantilevers ( $\geq 15 \mathrm{~mm}$ ) induced more implant-prosthesis failures as compared with cantilevers shorter than $15 \mathrm{~mm}$ (Shackleton et al. 1994). The results of the above studies indicated that a shorter cantilever length is more favorable for the success of mandibular fixed implantsupported prostheses, particularly critical for the prosthesis supported by less number of implants.

Several studies have reported that parafunctional activities (bruxism, clenching, etc.) and improper occlusal designs are correlated with implant bone loss/failure, implant fractures, and prosthesis failures (Falk et al. 1989, 1990; Naert et al. I992; Quirynen et al. 1992; Rangert et al. 1995). Naert et al. (I992) speculated that overload from parafunctional habits seemed to be the most probable cause of implant loss and marginal bone loss after loading. They also emphasized that the frequent occurrence of distal implant loss, eight out of $\mathrm{I} 2$ cases evaluated, might reflect the necessity of optimal spreading of implants, short cantilevers, and a proper occlusal design. Rangert et al. (I995) evaluated 39 fractured implant cases. Most of implant fractures, 35 out of $39(90 \%)$, occurred in the posterior area, and most of prostheses, 30 out of 39 , were supported by one or two implants with cantilever in association with heavy occlusal forces such as bruxism. In this study, in-line placement, leverage factors (cantilever), and bruxism or heavy occlusal force were suggested as the possible causes of implant fracture. Quirynen et al. (I992) reported that excessive marginal bone loss and/or implant loss were found in patients with lack of anterior contacts, the presence of parafunctional activities, and full-fixed implant-supported prostheses in both jaws. The retrospective study suggested a correlation between occlusal overloading resulting from those factors and severe marginal bone loss and/or loss of osseointegration. In contrast, in a prospective I 5 -year follow-up study, no notable correlation was found between implant marginal bone loss and load-related factors, such as bite force and cantilever length (Lindquist et al. 1996).
The different results between the above studies might have been attributed to individual variability of the patients and prosthetic condition and differences in occlusal designs. Falk et al. (I990) reported that the occlusal design (the number and distribution of occlusal contacts) had a major influence on the different force distribution between a cantilever segment and implant-supported area, increasing local forces significantly on the cantilever unit. In summary, it is implied that heavy occlusal force and undesirable distribution of occlusal contacts may be factors of overloading, thus possibly leading to higher susceptibility to implant bone loss, implant fractures/loss, and prosthesis failures.

Loss of osseointegration and excessive marginal bone loss from excessive lateral load provided with premature occlusal contacts were demonstrated in several animal studies (Isidor 1996, 1997; Miyata et al. 2000). In non-human primate studies, it was observed that five out of eight implants lost osseointegration due to excessive occlusal overloading after 4.5-I5.5 months of loading (Isidor 1996, I997). Among the three remaining implants, one showed severe crestal bone loss and the other two showed the highest boneimplant contact and density. The results suggested that implant loading might have significantly affected the responses of periimplant osseous structures. However, it should be noted that the loss of osseointegration observed might have been attributed to the unrealistically high-occlusal overload used in the study. Similar studies were performed in monkeys with different heights of hyperocclusion, I00, I80, and $250 \mu \mathrm{m}$ (Miyata et al. I998, 2000). After 4 weeks of loading, bone loss was observed in I 80 and $250 \mu \mathrm{m}$ group, not in the $100 \mu \mathrm{m}$ group. The results of these studies suggested that there would be a critical height of premature occlusal contacts on implant prostheses for crestal bone loss. Hoshaw et al. (1994) applied an excessive controlled cyclic load ( $330 \mathrm{~N} / \mathrm{s}, 500$ cycles, 5 days) on implants in canine tibia. Significant bone resorption and less mineralized bone percentage were observed in loading group compared with non-loading group. Another study demonstrated that excessive dynamic loading $(73.5 \mathrm{~N} \mathrm{~cm}$ bending moment and total 2520 cycles for 2 weeks) on implants placed in rabbit tibia caused 
crater-like bone defects lateral to implants (Duyck et al. 200I). Contradictory to the findings from the above studies, some studies have demonstrated that overloading did not increase marginal bone loss (Asikainen et al. 1997; Hürzeler et al. I998). The difference observed between the studies may be attributed to different magnitude and duration of applied force. Also, it should be noted that direct application of the findings from the animal studies to humans requires caution. Nonetheless, it can be speculated that occlusal overload may act as one of the factors causing marginal bone loss and implant failure.

Bone quality has been considered the most critical factor for implant success at both surgical and functional stages, and it is therefore suggested that occlusal overload in poor-quality bone can be a clinical concern for implant longevity (Lekholm \& Zarb I985; Misch I990a). In human studies, higher failures of implants were observed in bone with poor quality (Engquist et al. I988; Jaffin \& Berman I99 I; Becktor et al. 2002). Jaffin \& Berman (I99I) reported that $35 \%$ of implants placed in poor bone quality (i.e. posterior maxilla) failed at the second-stage surgery. However, it should be noted that all of the implants evaluated were Brånemark implants with a smooth pure-titanium surface, which is considered less favorable for poor quality bone (Cochran 1999). Some studies reported that higher implant failures in maxillary overdentures were attributed to poor bone quality of the maxilla (Engquist et al. I988; Quirynen et al. 1992; Hutton et al. I995). In addition to poor bone quality, unfavorable load direction may have contributed to higher failure rates in the maxilla (Jemt \& Lekholm 1995; Blomqvist et al. 1996; Raghoebar et al. 200I; Becktor et al. 2002). Esposito et al. (I997) found that late failure of implants did not show any infectious factor in histological evaluation. The combination of poor bone quality and overload was considered to be the leading cause for the late implant failure.

Misch (I990b) proposed that progressive bone loading can permit development time for load-bearing bone at bone-to-implant interface and provide bone with adaptability to loading via a gradual increase of loading. He further described that the progressive bone loading could be attained by the practice of increasing occlusal load over a time period of 6 months. Appleton et al. (I997) also noted that progressively loaded implants had increased bone density as well as reduced amounts of crestal bone loss. These findings suggest that extended healing time and carefully monitored loading may be needed in poor quality bone.

From the above studies, it can be speculated that (I) the amount of stress and the quality of the bone are related to implant longevity; (2) occlusal overloading, possibly resulting from large cantilevers, excessive premature contacts, parafunctional activities, improper occlusal designs, and/or osseointegrated full fixed prostheses in both jaws, can be a limiting factor for implant longevity (Table 2); (3) Even distribution of occlusal contacts avoiding occlusal interferences and increasing number of implants may significantly reduce occlusal overload on implants and implant prostheses; and (4) poor quality bone may be more vulnerable to occlusal overloading, which can be reduced by extended healing time and carefully monitored loading (e.g. progressive or delayed loading).

\section{Types and principles of implant occlusion}

The types and basic principles of implant occlusion have largely been derived from occlusal principles in tooth restoration. Three occlusal concepts (balanced, groupfunction, and mutually protected occlusion) have been established throughout clinical trials and conceptual theories (Pameijer 1983; Santos 1985; Hobo et al. 1989). All of the concepts may have maximum intercuspation (MIP) during habitual and/or centric occlusion. First of all, bilateral balanced occlusion has all teeth contacting during all excursions. It is primarily

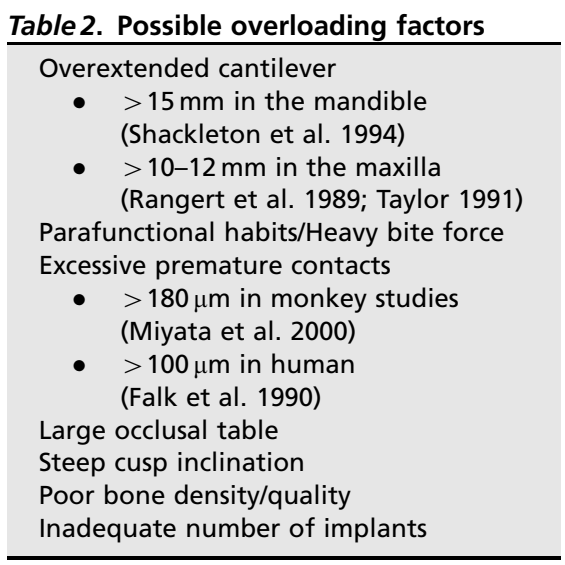

used in complete denture fabrication (Stuart 1955). In group-function occlusion, posterior teeth contact on the working side during lateral movements, without balancing side contacts. This occlusion is used primarily with compromised canines in order to share lateral pressures to posterior teeth instead of the canine (Schuyler 1959). Mutually protected occlusion has posterior teeth protection in habitual and/ or centric occlusion via posterior contacts in MIP while light contacts on anterior teeth and anterior guidance during all excursions. This occlusal scheme is based on the concept that the canine is a key element of occlusion avoiding heavy lateral pressures on posterior teeth (D'Amico I958). It has been considered a convenient and reasonable type of occlusal scheme for prosthetic rehabilitation, even though scientific evidence does not yet provide its clinical advantages (Pameijer I 983). These occlusal concepts (i.e. balanced, group-function, and mutually protected occlusion) have been successfully adopted with modifications for implant-supported prostheses (Adell et al. 1981; Chapman I989; Hobo et al. 1989; Naert et al. 1992; Lundgren \& Laurell I994; Wismeijer et al. I995; Mericske-Stern et al. 2000). Furthermore, implant-protected occlusion has been proposed strictly for implant prostheses (Misch \& Bidez 1994). This concept is designed to reduce occlusal force on implant prostheses and thus to protect implants. For this, several modifications from conventional occlusal concepts have been proposed, which include providing load sharing occlusal contacts, modifications of the occlusal table and anatomy, correction of load direction, increasing of implant surface areas, and elimination or reduction of occlusal contacts in implants with unfavorable biomechanics. Also, occlusal morphology guiding occlusal force to the apical direction, utilization of cross-bite occlusion, a narrowed occlusal table, reduced cusp inclination, and a reduced length of cantilever in mesio-distal and bucco-lingual dimension have all been suggested as factors to consider when establishing implant occlusion (Chapman 1989; Hobo et al. I989; Lundgren \& Laurell I994; Misch \& Bidez I994; Misch I999a).

Basic principles of implant occlusion may include (I) bilateral stability in centric (habitual) occlusion, (2) evenly distributed 
occlusal contacts and force, $(3)$ no interferences between retruded position and centric (habitual) position, (4) wide freedom in centric (habitual) occlusion, (5) anterior guidance whenever possible, and (6) smooth, even, lateral excursive movements without working/non-working interferences. Along with evenly distributed occlusal contacts, bilateral occlusal stability provides stability of the masticatory system and a proper force distribution (Beyron 1969). This can reduce the possibility of premature contacts and decrease force concentration on individual implants. In addition, wide freedom in centric can accomplish more favorable vertical lines of force and thus minimize premature contacts during function. Weinberg (1998) recommended continuous $\mathrm{I} .5 \mathrm{~mm}$ flat fossa area for wide freedom in centric in the prosthesis based on his clinical experience. In addition, Gibbs et al. (I98I) found that anterior or canine guidance decreased chewing force compared with posterior guidance. Quirynen et al. (1992) reported that lack of anterior contacts in an implant-supported cross-arch bridge created excessive marginal bone loss in posterior implants. The anterior or canine guidance could minimize potentially destructive forces in posterior implants. In addition to the advantage of the anterior guidance, smooth and even lateral working contacts without cantilever contacts in the posterior region may be preferred to provide proper force distribution and to protect the anterior region (Chapman 1989; Engelman 1996). It was suggested that working-side contacts should be placed as anteriorly as possible to minimize the bending moment (Lundgren \& Laurell I994).

Hobkirk \& Brouziotou-Davas (I996) evaluated masticatory force patterns of two occlusal schemes (balanced occlusion and group-function occlusion) with various foods in mandibular implant-supported prostheses. The mean peak masticatory force and load rate were lowest when eating bread and highest when chewing nuts, and the values of the mean peak masticatory force and load rate were lower with balanced occlusion compared with groupfunction occlusion upon chewing nuts and carrots. The study suggested that balanced occlusion might be more protective than group-function occlusion. However, Wennerberg et al. (200I) observed that occlusal factors in mandibular implantsupported prostheses opposing complete dentures did not influence patient satisfaction and treatment outcomes. It is implied that occlusal schemes may be less crucial factors of implant overloading than the number and position of occlusal contacts on implant prostheses.

Developing tooth morphology to induce axial loading is an important factor to consider when constructing implant prostheses. The axial loading on thread-type implants can be distributed well along the implant-bone interface, and the cortical bone can resist the compressive stress favorably (Reilly \& Burstein 1975; Misch I993; Rangert et al. 1997). A flat area around centric contacts can direct the occlusal force in an apical direction. Weinberg (I998) claimed that cusp inclination is one of the most significant factors in the production of bending moment. The reduction of cusp inclination can decrease the resultant bending moment with a lever-arm reduction and improvement of axial loading force. Kaukinen et al. (1996) investigated the difference of force transmission between $33^{\circ}$ and $0^{\circ}$ cusps. The mean initial breakage force of the $33^{\circ}$ cusped specimens was $3.846 \mathrm{~kg}$ while the corresponding value of the $0^{\circ}$ cuspless occlusal design specimens was $1.938 \mathrm{~kg}$. This result suggests that the cusp inclination affected the magnitude of forces transmitted to implant prostheses. In summary, a reduced cusp inclination, shallow occlusal anatomy, and wide grooves and fossae could be beneficial for implant prostheses.

The diameter and distribution of implants and harmonization to natural teeth are important factors to consider when deciding the size of an occlusal table. Typically $30-40 \%$ reduction of occlusal table in a molar region has been suggested, but any dimension larger than the implant diameter can create cantilever effects and eventual bending moments in singleimplant prosthesis (Misch I993; Rangert et al. 1997). A narrow occlusal table reduces the chance of offset loading and increases axial loading, which eventually can decrease the bending moment (Rangert et al. 1997; Misch I999a). Misch (I999a) described that a narrow occlusal table also improves oral hygiene and reduces risks of porcelain fracture. He further described that the posterior maxillary region with buccal bone resorption may enforce palatal placement of implants compared with the position of natural teeth. Normal occlusal contour on the palatally placed implant may create a significant buccal cantilever in a biomechanically poor environment (heavy bite, poor bone, and poor crown/ implant ratio). In this case, the utilization of cross-bite occlusion can avoid the buccal cantilever and increase the axial loading (Misch 1993; Weinberg 1998).

Force distribution between implants and natural teeth in a partially edentulous region can be accomplished with serial and gradient occlusal adjustments (Lundgren \& Laurell I994). Due to the non-significant mobility during initial tooth movement (3-5 $\mu \mathrm{m})$, implants may absorb all heavy biting force because natural teeth can be intruded $(25-50 \mu \mathrm{m})$ easily with any occlusal force. Misch (I993, I999a) proposed that occlusal adjustments could be performed by the elimination of mobility difference between implants and teeth under heavy bites. This approach may evenly distribute loads between implants and teeth. Over the years, natural teeth have positional changes in vertical and mesial direction while implants do not change their positions. In addition, enamel on the tooth wears more than porcelain on implant restorations. The positional changes of teeth may intensify the occlusal stress on implants. In order to prevent the potential overloading on implants from the positional changes, re-evaluation and periodic occlusal adjustments are imperative (Dario 1995; Rangert et al. 1997; Misch I999a).

\section{Clinical applications}

\section{Occlusion on full-arch fixed prostheses}

For full-arch fixed implant prostheses, bilateral balanced occlusion has been successfully utilized for an opposing complete denture, while group-function occlusion has been widely adopted for opposing natural dentition. Mutually protected occlusion with a shallow anterior guidance was also recommended for opposing natural dentition (Chapman 1989; Hobo et al. 1989; Wismeijer et al. I995). Bilateral and anterior-posterior simultaneous contacts in centric relation and MIP should be obtained to evenly distribute occlusal force during excursions regardless of the occlusal 
scheme (Chapman I989; Quirynen et al. I992; Lundgren \& Laurell I994). In addition, smooth, even, lateral excursive movements without working/non-working occlusal contacts on cantilever should be obtained (Lundgren \& Laurell I994; Engelman I996). For occlusal contacts, wide freedom $(\mathrm{I}-\mathrm{I} .5 \mathrm{~mm})$ in centric relation and MIP can accomplish more favorable vertical lines of force and thus minimize premature contacts during function (Beyron 1969; Weinberg 1998). Also, anteriorly placed working contacts were advocated to avoid posterior overloading (Hobo et al. I989; Taylor I991). When a cantilever is utilized in a full-arch fixed implant prosthesis, infraocclusion ( Ioo $\mu \mathrm{m})$ on a cantilever unit was suggested to reduce fatigue and technical failure of the prosthesis (Lundgren et al. I989; Falk et al. I990). Implant prostheses with less than I $5 \mathrm{~mm}$ cantilever in the mandible demonstrated significantly better survival rates than those with longer than I $5 \mathrm{~mm}$ cantilever (Shackleton et al. I994). On the other hand, less than IO-I $2 \mathrm{~mm}$ cantilever was recommended in the maxilla due to unfavorable bone quality and unfavorable force direction compared with the mandible (Rangert et al. I989; Taylor I99 I; Rodriguez et al. I994). Wie (I995) found that canine guidance occlusion increased a potential risk of screw joint failure at the canine site due to stress concentration on the area.

\section{Occlusion on overdentures}

For the occlusion on overdentures, it has been suggested to use bilateral balanced occlusion with lingualized occlusion on a normal ridge. On the other hand, monoplane occlusion was recommended for a severely resorbed ridge (Lang \& Razzoog I992; Wismeijer et al. I995; MericskeStern et al. 2000). Although there has been consensus that bilateral balance occlusion can provide better stability of overdentures (Engelman I996), there are no clinical studies which demonstrate the advantages of bilateral balanced occlusion for overdenture occlusion compared with other occlusal schemes. Recently, Peroz et al. (2003) performed a randomized, clinical trial comparing two occlusal schemes, balanced occlusion and canine guidance, in 22 patients with conventional complete dentures. The results of the assessment using a visual analog scale revealed that canine guidance was comparable to balanced occlusion in denture retention, esthetic appearance, and chewing ability.

\section{Occlusion on posterior fixed prostheses}

Anterior guidance in excursions and initial occlusal contact on natural dentition will reduce the potential lateral force on osseointegrated implants. Group-function occlusion should be utilized only when anterior teeth are periodontally compromised (Chapman I989; Hobo et al. I989; Misch \& Bidez I994). During lateral excursions, working and non-working interferences should be avoided in posterior restorations (Lundgren \& Laurell I994). Moreover, reduced inclination of cusps, centrally oriented contacts with a II. $5 \mathrm{~mm}$ flat area, a narrowed occlusal table, and elimination of cantilevers have been proposed as key factors to control bend overload in posterior restorations (Weinberg I998; Curtis et al. 2000). In a recent in vivo study, it was reported that narrowing the bucco-lingual width of the occlusal surface by $30 \%$ and chewing soft food significantly reduced bending moments on the posterior three-unit fixed prosthesis (Morneburg \& Pröschel 2003). The study also suggested that soft diet and reduction of the buccolingual, occlusal surface need to be considered in unfavorable loading conditions, such as immediate loading, initial healing phase, and/or poor bone quality.

Wennerberg \& Jemt (I999) described that additional implants in the maxilla could provide tripodism to reduce overloading and clinical complications. Also, axial positioning and reduced distance between posterior implants are important factors to decrease overloading (Belser et al. 2000). The utilization of cross-bite occlusion with palatally placed posterior maxillary implants can reduce the buccal cantilever and improve the axial loading (Misch I993; Weinberg I998). If the number, position, and axis of implants are questionable, natural tooth connection with a rigid attachment can be considered to provide additional support to implants (Rangert et al. I99 I; Belser et al. 2000; Naert et al. 200I).

\section{Occlusion on single implant prosthesis}

The occlusion in a single implant should be designed to minimize occlusal force onto the implant and to maximize force distribution to adjacent natural teeth (Misch I993; Lundgren \& Laurell I994; Engelman I996). To accomplish these objects, any anterior and lateral guidance should be obtained in natural dentition. In addition, working and non-working contacts should be avoided in a single restoration (Engelman I 996). Light contacts at heavy bite and no contact at light bite in MIP are considered a reasonable approach to distribute the occlusal force on teeth and implants (Lundgren \& Laurell I994). Like posterior fixed prostheses, reduced inclination of cusps, centrally oriented contacts with a I-I.5 mm flat area, and a narrowed occlusal table can be utilized for the posterior single tooth implant restoration (Weinberg I998; Curtis et al. 2000). Wennerberg \& Jemt (I999) claimed that centrally oriented occlusal contacts in single molar implants were critical to reduce bending moments attributable to mechanical problems and implant fractures. Increased proximal contacts in the posterior region may provide additional stability of restorations (Misch I999b). Two implants for a single molar have been utilized and demonstrated less screw loosening and higher success rates (Balshi et al. I996). However, the placement of two implants in a limited space is a challenging procedure, and difficulty in oral hygiene and prosthetic fabrication may develop. Instead of two implants in a single molar area, a wide-diameter implant with proper position and axis in a molar area could be a better option to reduce surgical and prosthetic difficulties and to improve oral hygiene and loading condition (Becker \& Becker I995; Chang et al. 2002). The occlusal guidelines in various clinical situations are summarized in Table 3.

\section{Potential complications and solutions}

Implant overloading attributes clinical complications such as screw loosening, screw fractures, fractures of veneering materials, prosthesis fractures, continuing marginal bone loss below the first thread along the implant, implant fractures, and implant loss (Zarb \& Schmitt I990; Jemt \& Lekholm I993; Wennerberg \& Jemt I999; Schwarz 2000). These complications can be prevented by application of sound biomechanical principles such as passive fit of the prosthesis, reducing cantilever length, narrowing the bucco-lingual/mesio-distal 
Table 3. Occlusal guidelines

\begin{tabular}{|c|c|}
\hline Clinical situations & Occlusal principles \\
\hline Full-arch fixed prosthesis & $\begin{array}{l}\text { - Bilateral balanced occlusion with opposing } \\
\text { complete denture } \\
\text { - Group function occlusion or mutually } \\
\text { protected occlusion with shallow anterior } \\
\text { guidance when opposing natural dentition } \\
\text { - No working and balancing contact on } \\
\text { cantilever } \\
\text { - Infraocclusion in cantilever segment }(100 \mu \mathrm{m}) \\
\text { - Freedom in centric }(1-1.5 \mathrm{~mm})\end{array}$ \\
\hline Overdenture & $\begin{array}{l}\text { - Bilateral balanced occlusion using lingulized } \\
\text { occlusion } \\
\text { - Monoplane occlusion on a severely resorbed } \\
\text { ridge }\end{array}$ \\
\hline Posterior fixed prosthesis & $\begin{array}{l}\text { - Anterior guidance with natural dentition } \\
\text { - Group function occlusion with compromised } \\
\text { canines } \\
\text { - Centered contacts, narrow occlusal tables, flat } \\
\text { cusps, minimized cantilever } \\
\text { - Cross bite posterior occlusion when necessary } \\
\text { - Natural tooth connection with rigid } \\
\text { attachment when compromised support }\end{array}$ \\
\hline Single implant prosthesis & $\begin{array}{l}\text { - Anterior or lateral guidance with natural } \\
\text { dentition } \\
\text { - Light contact at heavy bite and no contact at } \\
\text { light bite } \\
\text { - Centered contacts ( } 1-1.5 \mathrm{~mm} \text { flat area) } \\
\text { - No offset contacts } \\
\text { - Increased proximal contact }\end{array}$ \\
\hline Poor quality of bone/Grafted bone & $\begin{array}{l}\text { - Longer healing time } \\
\text { - Progressive loading by staging diet and } \\
\text { occlusal contacts/materials }\end{array}$ \\
\hline
\end{tabular}

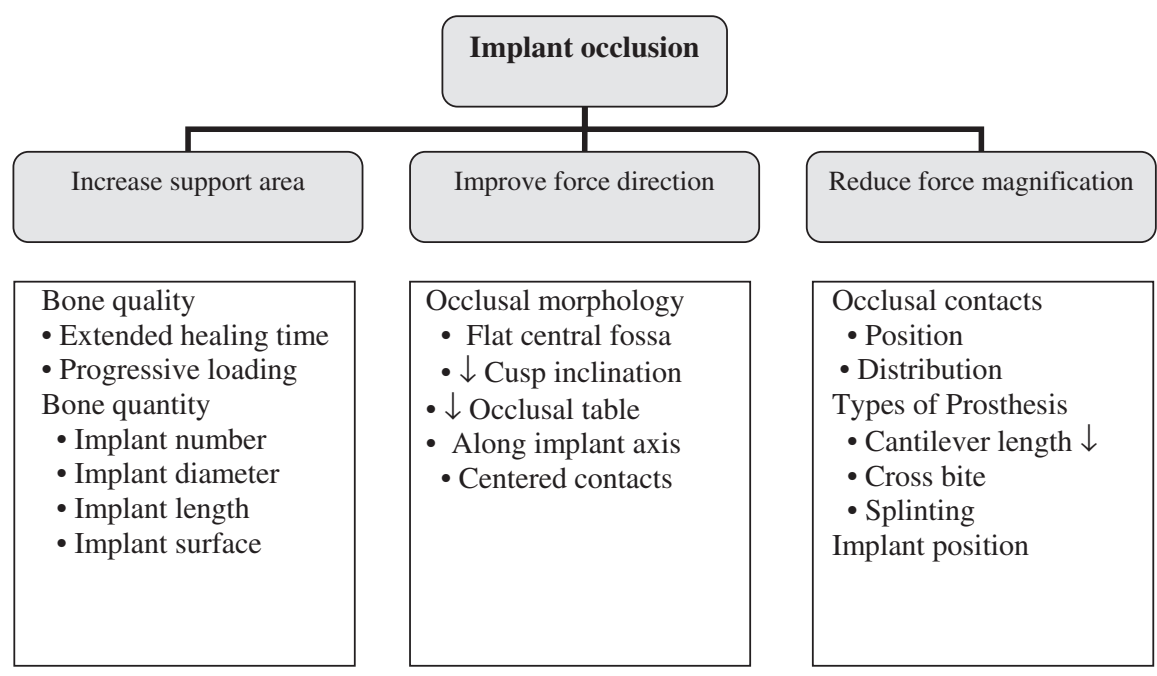

Fig. I. Factors to consider in implant occlusion.

dimension of the prosthesis, reducing cusp inclination, eliminating excursive contacts, and centering occlusal contacts (Zarb \& Schmitt I990; Jemt \& Lekholm I993; Rangert et al. I997; Wennerberg \& Jemt I999; Schwarz 2000). Furthermore, changing the type of prostheses and adding more implants are sometimes recommended (Cooper \& Moriarty I997).

\section{Summary}

The objectives of implant occlusion are to minimize overload on the bone-implant interface and implant prosthesis, to maintain implant load within the physiological limits of individualized occlusion, and finally to provide long-term stability of implants and implant prostheses. To accomplish these objectives, increased support area, improved force direction, and reduced force magnification are indispensable factors in implant occlusion (Fig. I). In addition, systematic, individualized treatment plans and precise surgical/ prosthodontic procedures based on biomechanical principles are prerequisites for optimal implant occlusion. Implant occlusion should be re-evaluated and adjusted, if needed, in a regular basis to prevent from developing potential overloading on dental implants, thus providing implant longevity. Currently, there is no evidence-based, implant-specific concept of occlusion. Future studies in this area are needed to clarify the relationship between occlusion and implant longevity.

Acknowledgements: This study was supported by the University of Michigan, Periodontal Graduate Student Research Fund.

Disclaimers: The authors do not have any financial interests, either directly or indirectly, in the products listed in the study.

\section{Résumé}

Vu l'absence de ligament parodontal, les implants ostéoïntégrés, contrairement aux dents naturelles, réagissent biomécaniquement d'une manière différente aux forces occlusales. Les implants dentaires seraient alors plus aptes à supporter la surcharge occlusale qui est souvent considérée comme une des causes potentielles de la perte osseuse paroïmplantaire et de l'échec des prothèses sur implants. Les facteurs de surcharge qui pourraient influencer négativement la longévité implantaire comprennent des porte-à-faux étendus, des parafonctions, des dessins occlusaux impropres et des contacts prématurés. Il est donc important au niveau des implants de contrôler l'occlusion dans une limite physiologique et donc d'apporter une charge implantaire optimale qui permette un succès implantaire à long terme. Les buts de ce manuscript ont été de discuter l'importance de l'occlusion implantaire dans la longévité implantaire et d'apporter des guides cliniques de l'occlusion implantaire optimale et des solutions possibles pour arranger les complications en relation avec l'occlusion implantaire. Aucune étude basée sur l'évidence ayant un concept spécifique de l'occlusion au niveau des implants n'existe 
actuellement. Davantage d'études dans ce domaine sont nécessaires afin de clarifier la relation entre occlusion et succès en implantologie.

\section{Zusammenfassung}

Weil ihnen das parodontale Ligament fehlt reagieren osseointegrierte Implantate biomechanisch auf okklusale Kräfte anders als natürliche Zähne. Man glaubte daher, dass Zahnimplantate anfälliger auf okklusale Überlastungen sind. Sie wurde somit auch als eine der Hauptursachen für den periimplantären Knochenverlust und den Misserfolg von Implantaten und implantatgetragenen Rekonstruktionen genannt. Faktoren, die zu einer Überlastung führen können und die sich negativ auf die Langzeitprognose von Implantaten auswirken können sind grosse Extensionsglieder, Parafunktionen, unsaubere Okklusionsgestaltung und Vorkontakte. Daher ist es wichtig, dass kontrolliert wird, ob die Okklusion der Implantate innerhalb der physiologischen Grenzen liegt, um so eine optimale Implantatbelastung und einen Langzeiterfolg für die Implantate zu garantieren. Die Ziele dieser Arbeit sind, die Wichtigkeit der Implantatokklusion für den Langzeiterfolg eines Implantates zu besprechen, klinische Richtlinien für eine optimale Implantatokklusion herauszuarbeiten und mögliche Lösungen zur Beherrschung von okklusionsbedingten Problemen bei Implantaten zu entwickeln. Es muss mit Nach- druck betont werden, dass es im Moment kein klinisch bewiesenes Okklusionskonzept spezifisch für Implantate gibt. Zukünftige Studien auf diesem Gebiet sollten in diese Richtung gehen und die Beziehung zwischen der Okklusion und dem Implantaterfolg klären.

\section{Resumen}

Debido a la ausencia de ligamento periodontal, los implantes osteointegrados, al revés que los dientes naturales, reaccionan biomecánicamente en una forma diferente a la fuerza oclusal. Por ello se cree que los implantes dentales pueden ser mas propensos a sobrecarga oclusal, la cual es frecuentemente considerada como una de las causas potenciales de pérdida ósea periimplantaria y fracaso de la prótesis implante/implante. Los factores de sobrecarga que pueden influir negativamente en la longevidad del implante incluyen largas piezas en extensión, parafunciones, diseños oclusales inadecuados, y contactos prematuros. Por lo tanto, es importante controlar la oclusión del implante dentro de limites fisiológicos y por ello suministrar una carga del implante óptima para asegurar un éxito del implante a largo plazo. Los propósitos de este artículo son discutir la importancia de la oclusión del implante para la longevidad de este y suministrar una guías clínicas para una oclusión óptima del implante y posibles soluciones para manejar las complicaciones relacio- nadas con la oclusión del implante. Se debe enfatizar que actualmente no existe un concepto específico de oclusión del implante basado en la evidencia. Son necesarios futuros estudios en esta área para clarificar la relación entre oclusión y éxito implantario.

要旨

骨性結合したインプラントは天然歯とは異なり菌 根膜がないために、咬合力に対して異なる様式で 生体力学的な反応をする。そのため歯牙インプラ ントは咬合力の過剩荷重になりやすいと考えられ ており、これがインプラント周囲の骨吸収やイン プラントイインプラント補緅物の失敗の主要な原 因の一つであるとみなされている。インプラント の寿命に悪影響を及ぼす過剩荷重の要因には、長 いカンチレバー、異常機能、不適切な咬合デザイ ンや早期接触が含まれる。従ってインプラントの 長期成功を確実にするためには、インプラントの 咬合を生理的な限界内に制御し、インプラントに 最適な荷重を付与することが重要である。本稿で は、インプラントの寿命に関連するインプラント 咬合の重要性を考察し、最適なインプラント咬合 の臨床的ガイドラインと、インプラント咬合に関 連する合併症に対処する解決策を提供する。今日 エビデンスに基づいた、インプラント固有の咬合 の概念というものは存在しないということを特筆 すべきであろう。本分野における今後の研究によ って咬合とインプラントの成功の関連性を明らか にすることが必要である。

キーワード: 歯牙インプラント、インプラント咬 合、過剩荷重、インプラントの寿命

\section{References}

Adell, R., Eriksson, B., Lekholm, U., Brånemark, P.I. \& Jemt, T. (1 990) Long-term follow-up study of osseointegrated implants in the treatment of totally edentulous jaws. International Journal of Oral 4 Maxillofacial Implants 5: 347-359.

Adell, R., Lekholm, U., Rockler, B. \& Brånemark, P.I. (I98I) A I5-year study of osseointegrated implants in the treatment of the edentulous jaw. International Journal of Oral Surgery ro: 387-4I6.

Appleton, R.S., Nummikoski, P.V., Pigmo, M.A., Bell, F.A. \& Cronin, R.J. (I997) Peri-implant bone changes in response to progressive osseous loading. Journal Dental Research $\mathbf{7 6}$ (special issue): 4I2 (Abstract 3I9I).

Asikainen, P., Klemetti, E., Vuillemin, T., Sutter, F., Rainio, V. \& Kotilainen, R. (I997) Titanium implants and lateral forces. An experimental study with sheep. Clinical Oral Implants Research 8: 465-468.

Balshi, T.J., Hernandez, R.E., Pryszlak, M.C. \& Rangert, B. (I996) A comparative study of one implant vs. two replacing a single molar. International Journal of Oral ↔) Maxillofacial Implants II: $372-378$.

Becker, W. \& Becker, B.E. (I995) Replacement of maxillary and mandibular molars with single endosseous implant restorations: a retrospective study. Journal of Prosthetic Dentistry 7: 5 I-55.

Becktor, J.P., Eckert, S.E., Isaksson, S. \& Keller, E.E. (2002) The influence of mandibular dentition on implant failures in bone-grafted edentulous maxillae. International Journal of Oral ↔ Maxillofacial Implants 17: 69-77.

Belser, U.C., Mericske-Stern, R., Bernard, J.P. \& Taylor, T.D. (2000) Prosthetic management of the partially dentate patient with fixed implant restorations. Clinical Oral Implants Research II (Suppl. I): I 26-I 45 .

Beyron, H.L. (I969) Optimal occlusion. Dental Clinics of North America 37: 537-554.

Blomqvist, J.E., Alberius, P., Isaksson, S., Linde, A. \& Hansson, B.G. (1996) Factors in implant integration failure after bone grafting: an osteometric and endocrinologic matched analysis. International Journal of Oral et Maxillofacial Surgery 25: 63-68.

Brånemark, P.I., Hannson, B.O., Adell, R., Breine, U., Lindstrom, J., Hallen, O., Ohman, A. (1977) Osseointegrated implants in the treatment of the edentulous jaw. Experience from a Io year period. Scandinavian Journal of Plastic @) Reconstructive Surgery 16 (Suppl.): I-I 32.

Chang, T.L., Roumanas, E., Jovanovic, S.A. \& Beumer III, J. (2002) Prosthetic aspects of dental implants. In: Newman, M.G., Takei, H.H. \& Carranza, F.A., eds. Carranza's clinical periodontology. 9th edition, 922-930. Philadelphia, London, New York, St. Louis, Sydney, Toronto: W.B. Saunders Co.

Chapman, R.J. (1989) Principles of occlusion for implant prostheses: guidelines for position, timing, and force of occlusal contacts. Quintessence International 20: 473-480.
Cho, G.C. \& Chee, W.W.L. (1992) Apparent intrusion of natural teeth under an implant-supported prosthsis: a clinical report. Journal of Prosthetic Dentistry 68: 3-5.

Cochran, D.L. (1999) A comparison of endosseous dental implant surfaces. Journal of Periodontology 70: I523-I 539 .

Cooper, L. \& Moriarty, J. (1997) Prosthodontic and periodontal considerations for implant-supported dental restorations. Current Opinion in Periodontology 4: I I9-I 26.

Curtis, D.A., Sharma, A., Finzen, F.C. \& Kao, R.T. (2000) Occlusal considerations for implant restorations in the partially edentulous patient. Journal of the California Dental Association 28: 77I-779.

D'Amico, A. (I958) The canine teeth: normalfunctional relation of the natural teeth of man. Journal of South California Dental Association 26: I-7.

Dario, L.J. (I995) How occlusal forces change in implant patients: a clinical research report. Journal of the American Dental Association 126: II3O-II33.

Duyck, J., Ronold, H.J., Van Oosterwyck, H., Naert, I., Vander Sloten, J. \& Ellingsen, J.E. (200I) The influence of static and dynamic loading on marginal bone reactions around osseointegrated implants: an animal experimental study. Clinical Oral Implants Research I2: 207-2 I 8.

Duyck, J., Van Oosterwyck, H., Vander Sloten, J., De Cooman, M., Puers, R. \& Naert, I. (2000) 
Magnitude and distribution of occlusal forces on oral implants supporting fixed prostheses: an in vivo study. Clinical Oral Implants Research I I: 465-475.

Engelman, M.J. (1996) Occlusion. In: Clinical decision making and treatment planning in osseointegration. Ist edition, I69-I76. Chicago: Quintessence Publishing Co.

Engquist, B., Bergendal, T., Kallus, T. \& Linden, U. (I988) A retrospective multicenter evaluation of osseointegrated implants supporting overdentures. International Journal of Oral \& Maxillofacial Implants 3: I29-I 34 .

Esposito, M., Thomsen, P., Molne, J., Gretzer, C., Ericson, L.E. \& Lekholm, U. (I997) Immunohistochemistry of soft tissues surrounding late failures of Brånemark implants. Clinical Oral Implants Research 8: 352-366.

Falk, H., Laurell, L. \& Lundgren, D. (I989) Occlusal force pattern in dentitions with mandibular implant-supported fixed cantilever prostheses occluded with complete dentures. International Journal of Oral \&) Maxillofacial Implants 4: 55-62.

Falk, H., Laurell, L. \& Lundgren, D. (I990) Occlusal interferences and cantilever joint stress in implant-supported prostheses occluding with complete dentures. International Journal of Oral $\Theta$ Maxillofacial Implants 5: 70-77.

Gibbs, C.H., Mahan, P.E., Lundeen, H.C., Brehnan, K., Walsh, E.K., Sinkewiz, S.L. \& Ginsberg, S.B. (I98I) Occlusal forces during chewing - influences of biting strength and food consistency. Journal of Prosthetic Dentistry 46: 56I-567.

Glantz, P.O. \& Nilner, K. (I998) Biomechanical aspects of prosthetic implant-borne reconstructions. Periodontology 2000 I7: I I9-I24.

Hämmerle, C.H., Wagner, D., Bragger, U., Lussi, A., Karayiannis, A., Joss, A. \& Lang, N.P. (I995) Threshold of tactile sensitivity perceived with dental endosseous implants and natural teeth. Clinical Oral Implants Research 6: 83-90.

Hillam, D.G. (I973) Stresses in the periodontal ligament. Journal of Periodontal Research 8 : $5 \mathrm{I}-56$.

Hobkirk, J.A. \& Brouziotou-Davas, E. (I996) The influence of occlusal scheme on masticatory forces using implant stabilized bridges. Journal of Oral Rehabilitation 23: 386-39I.

Hobo, S., Ichida, E. \& Garcia, L.T. (I989) Ideal occlusion. In: Osseointegration and occlusal rehabilitation. Ist edition, 3I 5-328. Tokyo, Berlin, Chicago, London, Sao Paulo, Hong Kong: Quintessence Publishing Company.

Hoshaw, S.J., Brunski, J.B. \& Cochran, G.V.B. (I994) Mechanical loading of branemark implants affects interfacial bone modeling and remodeling. International Journal of Oral \& Maxillofacial Implants 9: 677-683.

Hürzeler, M.B., Quinones, C.R., Kohal, R.J., Rohde, M., Strub, J.R., Teuscher, U. \& Caffesse, R.G. (I998) Changes in peri-implant tissues subjected to orthodontic forces and ligature breakdown in monkeys. Journal of Periodontology 69: 396-404.

Hutton, J.E., Heath, M.R., Chai, J.Y., Harnett, J., Jemt, T., Johns, R.B., McKenna, S., McNamara, D.C., van Steenberghe, D. \& Taylor, R. (I995) Factors related to success and failure rates at 3 - year follow-up in a multicenter study of overdentures supported by Branemark implants. International Journal of Oral et Maxillofacial Implants Io: 33-42.

Isidor, F. (I996) Loss of osseointegration caused by occlusal load of oral implants. A clinical and radiographic study in monkeys. Clinical Oral Implants Research 7: I43-I 52.

Isidor, F. (I997) Histological evaluation of periimplant bone at implants subjected to occlusal overload or plaque accumulation. Clinical Oral Implants Research 8: I-9.

Jacobs, R. \& van Steenberghe, D. (I993) Comparison between implant-supported prostheses and teeth regarding passive threshold level. International Journal of Oral et Maxillofacial Implants 8: 549-554.

Jaffin, R.A. \& Berman, C.L. (I99I) The excessive loss of Branemark fixtures in type IV bone: a 5 -year analysis. Journal of Periodontology 62: $2-4$.

Jemt, T. \& Lekholm, U. (1993) Oral implant treatment in posterior partially edentulous jaws: a 5year follow-up report. International Journal of Oral e) Maxillofacial Implants 8: 635-640.

Jemt, T. \& Lekholm, U. (I995) Implant treatment in edentulous maxillae: a 5-year follow-up report on patients with different degrees of jaw resorption. International Journal of Oral et Maxillofacial Implants Io: 303-3 I I.

Kaukinen, J.A., Edge, M.J. \& Lang, B.R. (I996) The influence of occlusal design on simulated masticatory forces transferred to implant-retained prostheses and supporting bone. Journal of Prosthetic Dentistry 76: 50-55.

Lang, B.R. \& Razzoog, M.E. (I992) Lingualized integration: tooth molds and an occlusal scheme for edentulous implant patients. Implant Dentistry I: 204-2 I I.

Lang, N.P., Wilson, T.G. \& Corbet, E.F. (2000) Biological complications with dental implants: their prevention, diagnosis and treatment. Clinical Oral Implants Research II (Suppl.): I46-I 55 .

Lekolm, U. \& Zarb, G.A. (I985) Patient selection and preparation. In: Branemark, P.I., Zarb, G.A. \& Albrektsson, T., eds. Tissue-integrated prostheses. Ist edition, I99-2 Iо. Chicago, London, Berlin, Rio de Janeiro, Tokyo: Quintessence Publishing Company.

Lindhe, J. \& Karring, T. (1998) Anatomy of perodontium. In: Lindhe, J., Kkarring, T. \& Lang, N.P., eds. Clinical periodontology and implant dentistry. 3rd edition, 45-49. Copenhagen: Munksgaaard.

Lindquist, L.W., Carlsson, G.E. \& Jemt, T. (I996) A prospective I5-year follow-up study of mandibular fixed prostheses supported by osseointegrated implants. Clinical results and marginal bone loss. Clinical Oral Implants Research 7: 329-336.

Lindquist, L.W., Carlsson, G.E. \& Jemt, T. (I997) Association between marginal bone loss around osseointegrated mandibular implants and smoking habit: a ro-year follow-up study. Journal of Dental Research 76: I667-I674.

Lindquist, L.W., Rockler, B. \& Carlsson, G.E. (I988) Bone resorption around fixtures in edentulous patients treated with mandibular fixed tissue-integrated prostheses. Journal of Prosthetic Dentistry 59: 59-63.

Lundgren, D., Falk, H. \& Laurell, L. (I989) Influence of number and distribution of occlusal cantilever contacts on closing and chewing forces in dentitions with implant-supported fixed prostheses occluding with complete dentures. International Journal of Oral $\leftrightarrow$ Maxillofacial Implants 4: 277-283.

Lundgren, D. \& Laurell, L. (I994) Biomechanical aspects of fixed bridgework supported by natural teeth and endosseous implants. Periodontology 2000 4: 23-40.

Mericske-Stern, R., Assal, P., Mericske, E. \& Burgin, W. (I995) Occlusal force and oral tactile sensibility measured in partially edentulous patients with ITI implants. International Journal of Oral et Maxillofacial Implants го: 345-353.

Mericske-Stern, R.D., Taylor, T.D. \& Belser, U. (2000) Management of the edentulous patient. Clinical Oral Implants Research II (Suppl. I): I08-I25.

Misch, C.E. (I990a) Density of bone: effect on treatment plans, surgical approach, healing, and progressive loading. International Journal of Oral Implantology 6: 22-3 I.

Misch, C.E. (I990b) Progressive bone loading. Practical Periodontics \&) Aesthetic Dentistry 7: 25-29.

Misch, C.E. (I993) Occlusal considerations for implant supported prostheses. In: Misch, C.E., eds. Contemporary implant dentistry. Ist edition, 705-733. St. Louis: Mosby.

Misch, C.E. (I999a) Occlusal considerations for implant supported prostheses. In: Misch, C.E., eds. Contemporary implant dentistry. 2nd edition, 609-628. St. Louis: Mosby.

Misch, C.E. (I 999 b) Endosteal implants for posterior single tooth replacement: alternatives, indications, contraindications, and limitations. Journal of Oral Implantology 25: 80-94.

Misch, C.E. \& Bidez, M.W. (I994) Implant-protected occlusion: a biomechanical rationale. Compendium I5: I330-I 344 .

Miyata, T., Kobayashi, Y., Araki, H., Motomura, Y. \& Shin, K. (r998) The influence of controlled occlusal overload on peri-implant tissue: a histologic study in monkeys. International Journal of Oral ef Maxillofacial Implants 3: 677-683.

Miyata, T., Kobayashi, Y., Araki, H., Ohto, T. \& Shin, K. (2000) The influence of controlled occlusal overload on peri-implant tissue. Part 3: a histologic study in monkeys. International Journal of Oral $\leftrightarrow$ Maxillofacial Implants 15 : 425-43I.

Morneburg, T.R. \& Pröschel, P.A. (2003) In vivo forces on implants influenced by occlusal scheme and food consistency. International Journal of Prosthodontics I6: 48 I-486.

Naert, I.E., Duyck, J.A., Hosny, M.M. \& Van Steenberghe, D. (200I) Freestanding and toothimplant connected prostheses in the treatment of partially edentulous patients. Part I: an up to I5years clinical evaluation. Clinical Oral Implants Research I2: 237-244.

Naert, I.E., Quirynen, M., van Steenberghe, D. \& Darius, P. (I992) A study of 589 consecutive 
implants supporting complete fixed prostheses. Part II: prosthetic aspects. Journal of Prosthetic Dentistry 68: 949-956.

Pameijer, J.H.N. (I983) Occlusion. In: Periodontal and occlusal factors in crown and bridge procedures. Ist edition, Vol. 85. Amsterdam: Dental Center for Postgraduate Courses.

Parfitt, G.J. (I960) Measurement of physiological mobility of individual teeth in an axial direction. Journal Dental Research 39: 608-6I8.

Peroz, I., Leuenberg, A., Haustein, I. \& Lange, K-P. (2003) Comparison between balanced occlusion and canine guidance in complete denture wearers - a clinical, randomized trial. Quintessence International 34: 607-6I2.

Quirynen, M., Naert, I. \& van Steenberghe, D. (I992) Fixture design and overload influence marginal bone loss and fixture success in the Brånemark system. Clinical Oral Implants Research $\mathbf{3}$ IO4-III.

Raghoebar, G.M., Timmenga, N.M., Reintsema, H., Stegenga, B. \& Vissink, A. (200I) Maxillary bone grafting for insertion of endosseous implants: results after I2-I24 months. Clinical Oral Implants Research I2: 279-286.

Rangert, B., Gunne, J. \& Sullivan, D.Y. (I99I) Mechanical aspects of a Branemark implant connected to a natural tooth: an in vitro study. International Journal of Oral 4 Maxillofacial Implants 6: $177-\mathrm{I} 86$.

Rangert, B., Jemt, T. \& Jorneus, L. (I989) Forces and moments on Branemark implants. International Journal of Oral $\oplus$ Maxillofacial Implants 4: $24 \mathrm{I}-247$.

Rangert, B., Krogh, P.H., Langer, B. \& Van Roekel, N. (I995) Bending overload and implant fracture: a retrospective clinical analysis. International Journal of Oral @ Maxillofacial Implants ro: 326-334.

Rangert, B.R., Sullivan, R.M. \& Jemt, T.M. (I997) Load factor control for implants in the posterior partially edentulous segment. International Jour- nal of Oral ↔ Maxillofacial Implants $\mathbf{1 2}$ : 360-370.

Reilly, D.T. \& Burstein, A.H. (I975) The elastic and ultimate properties of compact bone tissue. Journal of Biomechanics 8: 393-405.

Richter, E.J. (I 998) In vivo horizontal bending moments on implants. International Journal of Oral e) Maxillofacial Implants I3: 232-244.

Rodriguez, A.M., Aquilino, S.A. \& Lund, P.S. (1994) Cantilever and implant biomechanics: a review of the literature, Part 2. Journal of Prosthodontics 3: I I4-I I8.

Rosenberg, E.S., Torosian, J.P. \& Slots, J. (I99I) Microbial differences in 2 clinically distinct types of failures of osseointegrated implants. Clinical Oral Implants Research 2: I35-I 44.

Santos, J. Jr (I985) Concepts of occlusion. In: Occlusion: principles and concepts, I79-I90. St. Louis, Tokyo: Ishiyaku EuroAmerica, Inc.

Schroeder, A., Polher, O. \& Sutter, F. (I976) Gewebs-reaktion auf ein Titan-Hohlzylinderimplantat mit Titan-Spritzschichtoberfläche (in German). Schweizerische Monatsschrift für Zahnheilkunde 86: 7I 3-727.

Schulte, W. (1995) Implants and the periodontium. International Dental Journal 45: 16-26.

Schuyler, C.H. (I959) Considerations of occlusion in fixed partial dentures. Dental Clinics of North America 37: 175-I85.

Schwarz, M.S. (2000) Mechanical complications of dental implants. Clinical Oral Implants Research II (Suppl.): I 5 6-I 58.

Sekine, H., Komiyama, Y., Hotta, H. \& Yoshida, K. (I986) Mobility characteristics and tactile sensitivity of ossointegrated fixture-supporting systems. In: van Steenberghe, D., eds. Tissue integration in oral maxillofacial reconstruction, 326-332. Amsterdam: Excerpta Medica.

Shackleton, J.L., Carr, L., Slabbert, J.C. \& Becker, P.J. (I994) Survival of fixed implant-supported prostheses related to cantilever lengths. Journal of Prosthetic Dentistry 71: 23-26.
Stuart, C.E. (I 955 ) Articulation of human teeth. In: Collum, B.B. \& Stuart, C.E., eds. A research report, 9I-I23. South Pasadana, CA: Scietific press.

Taylor, T.D. (I99I) Fixed implant rehabilitation for edentulous maxilla. International Journal of Oral 4) Maxillofacial Implants I3: 539-545.

Taylor, T.D., Belser, U. \& Mericske-Stern, R. (2000) Prosthodontic considerations. Clinical Oral Implants Research II (Suppl.): IOI-I07.

Tonetti, M. \& Schmid, J. (I994) Pathogenesis of implant failures. Periodontology $2000 \quad 4$ : I 27-I 38 .

Weinberg, L.A. (I 998) Reduction of implant loading with therapeutic biomechanics. Implant Dentistry 7: 277-285.

Wennerberg, A., Carlsson, G.E. \& Jemt, T. (200I) Influence of occlusal factors on treatment outcome: a study of Io9 consecutive patients with mandibular implant-supported fixed prostheses opposing maxillary complete dentures. International Journal of Prosthodontics I4: 550-555.

Wennerberg, A. \& Jemt, T. (I999) Complications in partially edentulous implant patients: a 5-year retrospective follow-up study of I 33 patients supplied with unilateral maxillary prostheses. Clinical Implant Dentistry $\oplus$ Related Research $\mathbf{I}$ : 49-56.

Wie, H. (I995) Registration of localization, occlusion and occluding materials for failing screw joints in the Branemark implant system. Clinical Oral Implants Research 6: 47-53.

Wismeijer, D., van Waas, M.A. \& Kalk, W. (I995) Factors to consider in selecting an occlusal concept for patients with implants in the edentulous mandible. Journal of Prosthetic Dentistry 74: 380-384.

Zarb, G.A. \& Schmitt, A. (I990) The longitudinal clinical effectiveness of osseointegrated dental implants: the Toronto study. Part III: problems and complications encountered. Journal of Prosthetic Dentistry 64: I 85-I94. 